\title{
A Percepção do Caos Urbano, as Enchentes e as suas Repercussões nas Políticas Públicas da região Metropolitana de São Paulo
}

\section{Urban Chaos Perception, Floods and Repercussions on Public Polities in São Paulo Metropolitan Area}

\author{
Ailton Pinto Alves Filho \\ Doutor em Geografia Física - FFLCH-USP - Pós-doutorando FSP-USP \\ E-mail: ailtonlineœusp.br \\ Helena Ribeiro \\ Profa Livre Docente - FSP-USP \\ E-mail: lenaळusp.br
}

\section{Resumo}

Um aspecto muito discutido na atualidade, por pesquisadores dos fenômenos urbanos, é a percepção dos riscos ambientais. No caso da sociedade brasileira em geral, existe a concepção dominante de que os modelos de expansão urbanos, adotados nas grandes metrópoles, são responsáveis por graves problemas geoecológicos, que estas apresentam. No entanto, esta percepção não é muito clara e muda constantemente, evoluindo por força dos acontecimentos.

No caso da RMSP - Região Metropolitana de São Paulo, os riscos hídrico-meteóricos são constantemente invocados como graves, merecendo, por parte dos poderes públicos, grande atenção. 0 presente artigo analisa os mecanismos decisórios e as políticas publicas, tomadas em função da percepção de caos urbano decorrente de grandes episódios de inundação, entendidos aqui como aqueles capazes de literalmente paralisar o ritmo diário de uma metrópole como São Paulo. Considera-se uma situação caótica como aquela capaz de provocar a interrupção do sistema de transportes, impedir a livre circulação de pessoas e mercadorias, gerar enormes prejuízos financeiros e materiais; suscitando o aparecimento de grande número de vítimas. Esta percepção de risco será confrontada com os dados climatológicos de cada situação calamitosa e também com as repercussões destes eventos nos processos decisórios. Pretende-se, desta forma, contribuir com o aperfeiçoamento do planejamento urbano, na gestão compartilhada das águas, e também com o estabelecimento de padrões de análise nos quais se possam verificar os progressos ou retrocessos na gestão deste recurso.

Palavras-chave: Gestão Urbana; Enchentes; Políticas Públicas; Climatologia Urbana. 


\section{Abstract}

Nowadays, investigation on environmental risk perception is very popular among urban phenomena researchers. Generally, in Brazilian society, there is a belief that the more important large cities geo-ecological problems are connected to non-planned urban expansion. However, this perception is not very clear and changes constantly, according to new events. In the case of São Paulo Metropolitan Area, the hydrometeorological risks are considered serious problems and call attention of governments. In this paper we analyzed the decisions mechanisms and the public policies adopted to control urban chaos, after a great flooding episode. There are the situations that literally paralyze a daily rhythm of a metropolis like São Paulo. We mention in this approach, the cases when interruptions of the transportation systems, of products and people's circulation, material and financial damages and, finally, great number of victims occur. Climatological data is confronted to society's risk perception and also to the decisions taken by the governments in these cases. Thus, the objectives of this paper were to contribute to urban planning improvements, to the management of shared waters process and also to provide indicators for better analysis and management of these resources.

Keywords: Urban Management, Environmental risks, Floodings, Urban Climatology.

\section{Introdução}

Historicamente, a adoção na Bacia Hidrográfica do Alto Tietê, de um modelo de gerenciamento hídrico totalmente artificial, que depende de permanentes e vultosos recursos para sua gestão, manutenção e sustentabilidade constantemente despertou algum questionamento por parte da sociedade. Porém, uma gestão centralizadora dos mecanismos decisórios sempre prevaleceu, definindo quando e como se devem investir os recursos do erário público.

As enchentes, que periodicamente ocorrem em São Paulo, deveriam levar a sociedade a indagações sobre o modelo de ocupação urbana utilizada e a influência deste no recrudescimento do processo. No entanto, muito pelo contrário, as enchentes servem, via de regra, como argumentos para justificar investimentos que reforçam o modelo vigente, sem que haja maiores contestações. O reconhecimento de uma situação de caos urbano pode ser utilizado como estratégia discursiva e de ação política para justificar a priorização de investimentos em determinadas áreas da metrópole e no adiamento de outras. Há ainda o inconveniente de que o reconhecimento do caráter prioritário ou emergencial de determinadas obras anti-enchentes possa esvaziar os mecanismos colegiados criados, na década passada, para enfrentar os problemas hídricos.

É obvio que a repercussão dos episódios pluviais intensos dá-se de forma desigual, social e territorialmente, pois esses eventos têm um significado diferente para uma família que teve seu barraco alagado, para outros que ficaram presos num ônibus por muitas horas num congestionamento gigantesco e para quem assistiu tudo pela televisão. Desta forma é importante a realização de pesquisas nos mais variados campos, que permitam uma melhor compreensão da realidade de nossas cidades, facilitando acesso às informações e ampliando a percepção e a consciência sobre a saúde ambiental urbana e possibilitando ações orientadas para solução dos problemas de interesse coletivo.

Eventos Extremos e a Distribuição das Chuvas na Região Metropolitana de São Paulo

Analisando-se a variação anual da precipitação de postos meteorológicos de São Paulo que possuem longas séries históricas de dados é possível encontrarmos 
uma tendência ao aumento da precipitação nos últimos trinta anos. Infelizmente, fica difícil a comparação entre dados de diversos postos, pois, não raro, há falhas ou incongruências nas leituras.

Tomando-se por base uma série de trinta anos de dois postos meteorológicos da cidade de São Paulo com boa consistência de dados, um deles um pouco afastado do centro, que sofre menos impacto da urbanização (IAG - Instituto Astronômico e Geofísico) e outro próximo da área central da cidade (Instituto Bio- lógico) nas proximidades do espigão da Avenida Paulista, verifica-se em ambos a presença de coeficientes lineares positivos, ou seja, houve uma leve tendência ao aumento da precipitação.

Em outros postos, esta tendência também se verifica, porém são raras as séries contínuas de dados consistentes para serem apresentados. É interessante notar que, no posto do Instituto Biológico mais central, há um indicativo de aumento de pluviosidade ligeiramente maior que do IAG. (Figura 1)

Figuraı - Histograma representativo da variação da pluviosidade anual dos postos do IAG-USP (E3-035) e do Instituto Biológico (E3-090) entre 1967 a 2002 ( $\mathrm{em} \mathrm{mm}$ ) e suas respectivas linhas de tendência

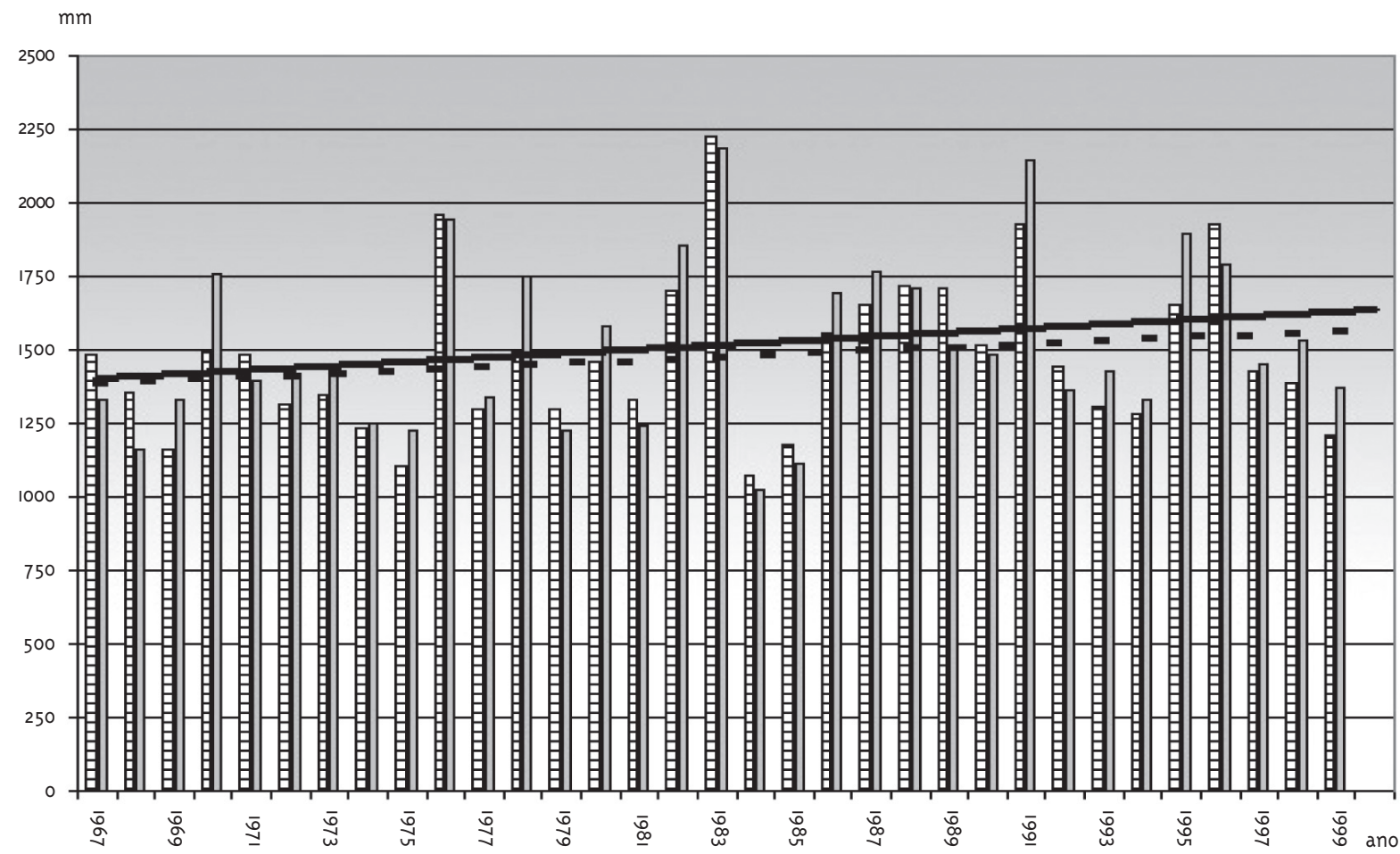

Legenda

E3-035 IAG

E3-090 - Inst. Biológico

- - Linear (E3-035 IAG)

- Linear (E3-090 - Inst. Biológico) 
Embora haja este indicativo para o aumento da precipitação na RMSP - Região Metropolitana de São Paulo, tem-se que guardar alguns cuidados com a interpretação dos resultados, pois estas evidências podem representar uma tendência geral observada no estado de São Paulo, como as que aparecem nos seis gráficos de dispersão e suas respectivas retas de regressão (Figura 2).

Estes gráficos, que abrangem postos espalhados por diversas localidades do território paulista, sinalizam com evidências do aumento das precipitações, principalmente naqueles situados na porção mais a leste do estado. De acordo com Ambrizzi (2001), a precipitação anual acumulada vem aumentando nos últimos cinqüenta anos no Estado de São Paulo, embora ainda não sejam conclusivos se os motivos para tal relacionam-se com mudanças no padrão geral de circulação da atmosfera.

\section{Figura 2 - Gráficos de dispersão e das tendências na variação da pluviosidade anual de postos selecionados do estado de São Paulo - de 1967 a 1997 (em mm)}

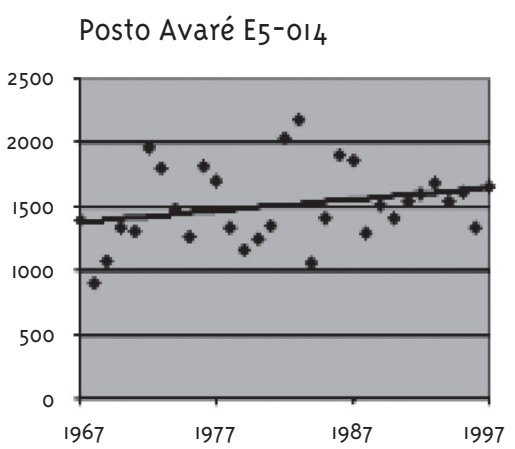

Posto Maresias E2-124 (S. Sebastião)

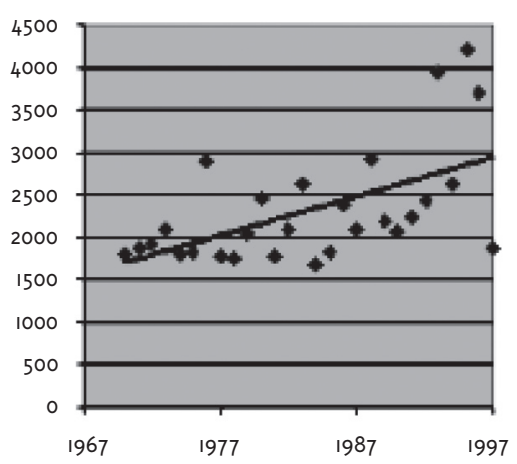

Posto Andradina B8-004

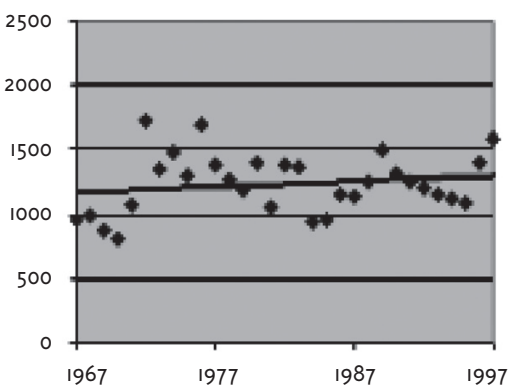

Posto Barretos $\mathrm{B} 5^{-002}$

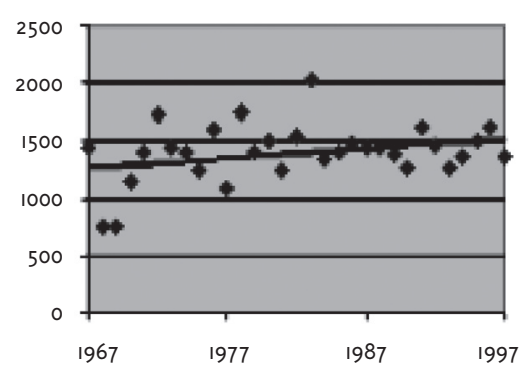

Posto Bauru D6-096

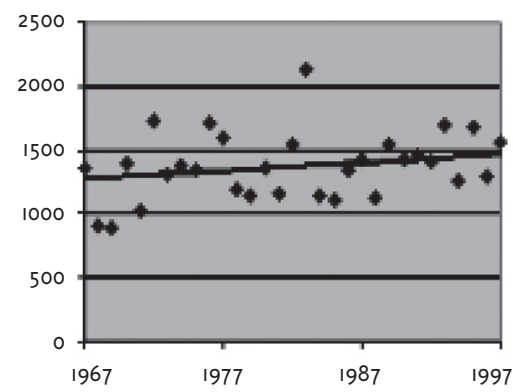

Posto P. Prudente D8-003

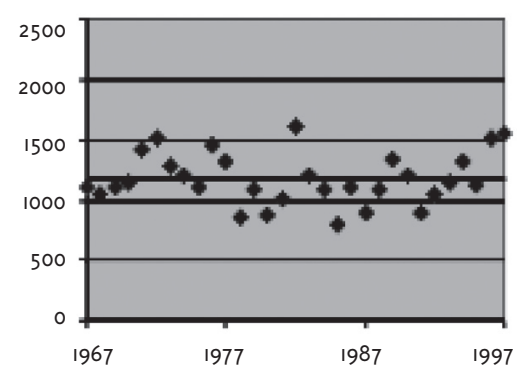

Elaboração: Ailton Pinto Alves Filho, Fonte: DAEE - Banco de Dados Pluviométricos do Estado de São Paulo

A posição da RMSP numa área de transição, que sofre influências das principais correntes de circulação atmosféricas da América do Sul, favorece a uma grande variabilidade climática de ano para ano. Corroboram para esta imprevisibilidade: as distintas ações das correntes tropicais marítimas, dos fluxos polares, dos fluxos provenientes do interior do continente, das caracte- rísticas intra-urbanas e de suas inúmeras combinações.

Apenas para servir de referência, foram calculadas as médias por decênio de alguns postos pluviométricos da cidade de São Paulo, constatando-se uma tendência ao aumento da pluviosidade. 0 destaque é a década de oitenta, quando houve o episódio ENOS-El Niño/Oscilação Sul mais intenso do século XX (Figura 3) 
Figura 3 - Histograma representativo da média de pluviosidade por década (em $\mathrm{mm}$ ) em postos meteorológicos da cidade de São Paulo entre 1930 e 2000 e linha de tendência

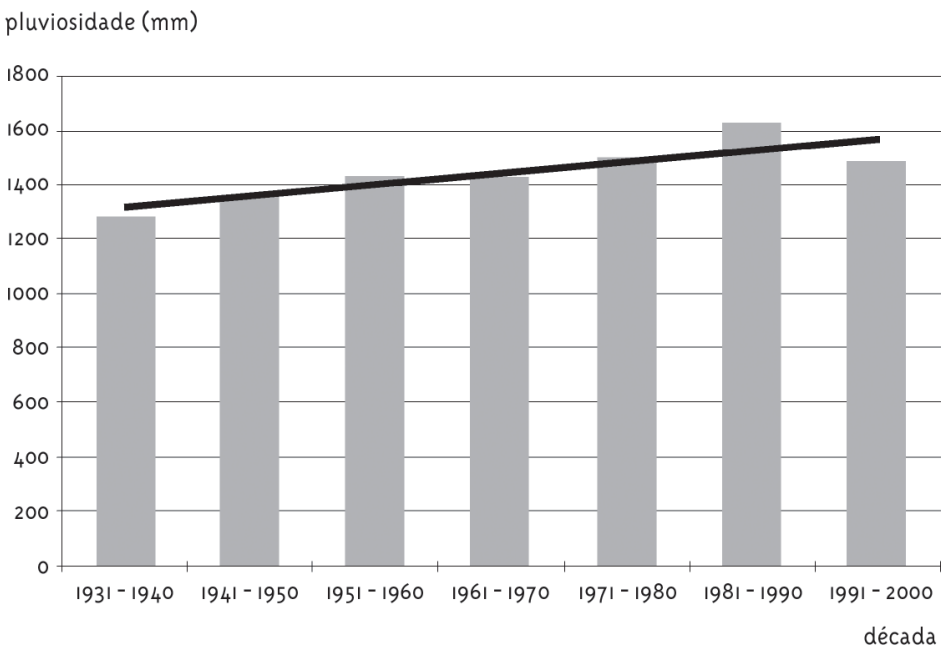

Fonte: DAEE - Banco de Dados Pluviométricos do Estado de São Paulo

Mais do que a média, o que é relevante nestas situações é que o acréscimo neste volume total de chuvas dá-se como decorrência de poucos, ou às vezes de um único evento extremo, como são os caso dos episódios que marcaram janeiro de 1987, dezembro de 1988 e julho de 1989. Trabalha-se com a hipótese de que, entre as características endógenas que estão reforçando estes padrões, estão as alterações climáticas provocadas pela urbanização.

Se, por um lado, são identificadas mudanças significativas nas propriedades físicas da atmosfera da metrópole, temos, por outro, ao nível da superfície, profundas alterações no sistema hidrológico e no uso do solo, evidenciadas pelo fato de que a área urbanizada se estende hoje por mais de dois mil e cem quilômetros quadrados ${ }^{1}$. Este conjunto de características configura um cenário de sujeição a grandes riscos. De acordo com os critérios de agrupamentos utilizados por Monteiro (1984), tais situações são reconhecidas como aquelas capazes de paralisarem a vida da metrópole, induzindo a uma percepção de caos urbano. Inclui-se neste critério: bairros alagados com pessoas ilhadas, tráfegos ferroviário e rodoviário interrompidos, vias bloqueadas, grandes congestionamentos, desabamentos, populações desabrigadas, interrupção no fornecimento de serviços públicos, prejuízos nas industrias, no comercio e nos serviços.

\section{O Clima, as Enchentes e as Políticas Públicas na Região Metropolitana de São Paulo}

A transformação da cidade de São Paulo de um pequeno núcleo provinciano na grande metrópole nacional tem como marco o final do século dezenove, quando pela primeira vez, ela conseguiu expandir-se para além do sítio original, localizado numa colina no interflúvio entre duas várzeas inundáveis (Silva,1958). A conquista para a cidade de alagadiços e a sua posterior ocupação se tornou um grande negócio, uma vez que a área saneada passou a ser explorada por consórcios realizadores de tais empreendimentos.

A história da ocupação da Bacia Hidrográfica do Alto Tietê, desde o final do século XIX até a época atual, confunde-se com a história da apropriação da maior parte dos recursos hídricos em função de seu uso para produção energética e para a sua adaptação à expansão urbana. A demanda por energia propiciou a realização de uma série de intervenções na bacia hidrográfica do Alto Tietê, com a construção de barragens, reservatórios e bombas de recalque, que causam problemas até hoje. 
Entre estas obras, engendradas pela empresa canadense Light \& Power, que tinha o monopólio da geração de energia, pode-se citar a construção da barragem de Santana de Parnaíba (mais tarde Edgar de Souza), em 1901, que passou a represar as águas do Tietê à jusante da capital.

Em 1926, foram realizadas obras que permitiram reversão de fluxo do Rio Pinheiros (afluente da margem esquerda do Tietê). Numa ousada obra de engenharia, suas águas passaram a ser encaminhadas para um novo sistema de reservatórios na borda do planalto - inaugura-se assim o Sistema Billings. No último destes reservatórios, o de Rio das Pedras, a água passou a descer por dutos forçados pela Encosta Serrana Paulista, numa queda de mais de 700 metros, para movimentar a usina Henry Borden. (Eletropaulo,1995).

Assim, com intuito de gerar de energia, houve a inversão da vazão hidrográfica que faz com que as águas barradas em Edgar de Souza possam dirigir-se para a represa Billings, criando-se, desta forma, um grande lago que corta a cidade de São Paulo. As águas, assim represadas nos cursos principais e indiretamente por ação do refluxo nos seus tributários, passaram a constituir-se num risco constante para a cidade e seus municípios contíguos, tanto pelo lado sanitário, pois são os receptáculos finais dos esgotos, como também pelo lado da sujeição periódica da bacia aos alagamentos².

A implantação de um sistema totalmente artificial, que depende de permanentes e vultosos recursos para seu gerenciamento e manutenção sempre desperta algum questionamento por parte da sociedade. Porém, uma gestão centralizadora dos mecanismos decisórios sempre prevaleceu, definindo quanto e no que se devem investir os recursos do erário público.

As enchentes, que periodicamente ocorrem em São Paulo, deveriam levar a população a indagações sobre o modelo de ocupação urbana e o seu papel no favorecimento do processo, mas, pelo contrário, muitas vezes elas foram utilizadas para justificar investimentos e promover mais especulação imobiliária. Um dos momentos emblemáticos deste processo, pesquisado por Seabra (1987), foi o das enchentes de 1929.

No mês de fevereiro daquele ano, ocorreram chuvas intensas sobre São Paulo, aparentemente nada que fuja aos padrões esperados para o mês de fevereiro. Porém, a certeza da magnitude do fenômeno só seria possível de ser apurada se tivéssemos disponíveis registros pluviográficos efetuados nas proximidades da bacia do reservatório da Guarapiranga. Os dados disponíveis, que se referem ao posto meteorológico da Estação da Luz (Figura 4), indicam volumes de chuvas consideráveis, mas relativamente comuns para o período do ano. Ao todo, entre os dias seis e treze de fevereiro, choveram 246,4 mm na Luz. Porém, estes dados servem apenas como referência, pois devido à variabilidade das precipitações no regime de verão, as chuvas sobre a Guarapiranga podem ter sido muito mais intensas.

\section{Figura 4 - Histograma representativo da precipitação diária em fevereiro de 1929 ( $\mathrm{em} \mathrm{mm}$ ) no Posto Pluviométrico da Estação da Luz}

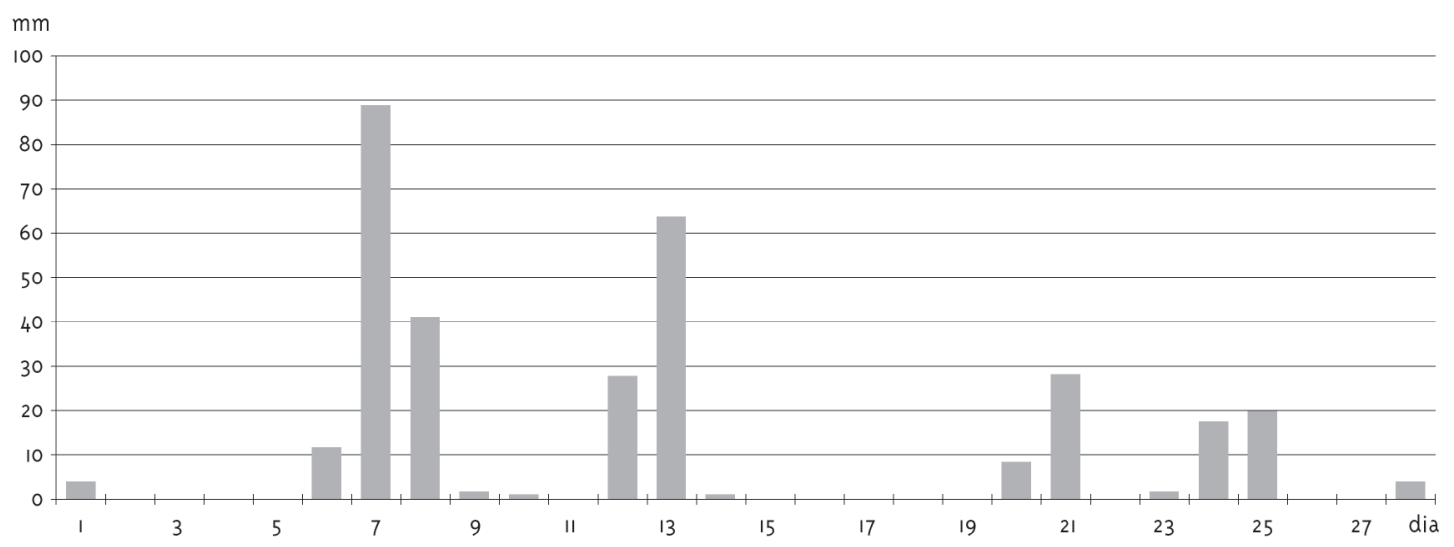

Fonte: DAEE - Banco de Dados Pluviométricos do Estado de São Paulo

2 A descarga de esgoto do Tietê para do Canal do Pinheiros e deste para esse reservatório Billings é proibida, (salvo exceções previstas) na (Constituição Estadual de 1.989, Art. 46 do ato das Disposições Transitórias e Resolução Conjunta SMA/SES - o3/92). 
A cidade sofreu uma inundação inusitada, pois, no dia quatorze de fevereiro, a Companhia Light \& Power abriu as comportas das represas controladas por ela (Billings e Guarapiranga), que haviam acumulado nos seus reservatórios as descargas pluviais ocorridas entre os dias seis e treze de fevereiro, e fechou as comportas da barragem de S. Parnaíba (Edgar de Sousa). Assim, houve uma elevação do nível dos rios da Bacia do Alto Tietê, inundando grande parte da cidade, particularmente a várzea do Rio Pinheiros. Com isso, a Light \& Power pôde demarcar, como zona de extravasamento do rio, imensas áreas alagadas no evento, o que vinha ao encontro dos interesses da companhia. Dois anos antes, o Governo do Estado havia dado concessão para que esta empresa e suas subsidiárias pudessem explorar comercialmente toda a área considerada como várzea deste rio (Eletropaulo, 1995 op. cit.). Além de novas linhas de bondes elétricos, bairros inteiros foram erigidos dentro desta área de concessão (Seabra 1987 op. cit.).

A partir da década de sessenta do século XX, intensificou-se o processo de retificação dos cursos dos principais rios da Bacia do Alto Tietê. Obras de combate às enchentes e para aumento de vazão de escoamento passaram a fazer parte do cotidiano da metrópole. Entre 1961 e 1971, várias obras de corte e retificação foram realizadas, entre Osasco e Barragem de Edgar de Souza, para aumentar a vazão do sistema. A extensão do canal retificado ficou em 13.10om, com a redução em 7.70om da distância entre Edgar de Souza e Osasco. Já na década de setenta, foram executadas obras à montante, nas barragens próximas às cabeceiras, como as de Taiaçupeba e Ponte Nova, para regularização do regime fluvial.

Em 1975, foi lançado o projeto SANEGRAN que pretendia tratar os esgotos da RMSP em grande escala, com a construção de estações dentro da Região Metropolitana. Este projeto causou muita polêmica sendo alvo de inquéritos processuais (Victorino, 2003). $\mathrm{Na}$ sua primeira fase, que deveria ser concluída em
1983, trataria 15 m³/s de esgoto, mas, àquela época, sua capacidade chegou a apenas um décimo deste volume, tendo consumido mais de US\$ 1 bilhão de investimentos (Victorino, 2003 op. cit.).

Um evento marcante de inundação ocorreu entre 29 e 30 de janeiro 1976, com registros de volumes de chuvas acumulados, nestes dois dias, superiores a 250 mm. Este episódio coincidiu com a ação de um fenômeno de El Niño ${ }^{3}$. Naquela ocasião, houve sério risco de ruptura do reservatório da Guarapiranga, cuja estrutura teve que ser reforçada com sacos de areia para evitar alagamento dos bairros contíguos ${ }^{4}$. Naquele mesmo ano, foi criado o Sistema Estadual de Defesa Civil (Decreto ${ }^{0}{ }^{7} \cdot 550$ ) e o primeiro Comitê Especial de Bacias Hidrográficas, formulado a partir de um acordo entre o Governo do Estado de São Paulo e o Ministério das Minas e Energia para melhoria das condições sanitárias e solução dos conflitos hídricos nas bacias do Tietê e Cubatão 5 .

Inaugurou-se, também naquele ano, parte do sistema Cantareira, que promoveu inicialmente o desvio das águas das nascentes das bacias do Rio Piracicaba (Rio Atibaia) para abastecimento da Região Metropolitana de São Paulo e que foi sendo posteriormente ampliado (Massari; Reydon 2005). Desta forma, um grande volume de águas das Bacias dos rios Piracicaba, Capivari, Jundiaí (cerca de $31 \mathrm{~m} / \mathrm{s}$ atualmente) passou a ser desviado para Bacia do Alto Tietê. Depois de utilizadas, as águas são despejadas na Bacia do Alto Tietê, na forma de esgoto.

A partir de 1977, diversos levantamentos foram realizados pelo DAEE - Departamento de Águas e Energia Elétrica do Estado de São Paulo e pela PROMOM Engenharia S/A, na busca de soluções para as enchentes ${ }^{6}$.

No período entre 1982 e 1983, ocorreu o mais forte fenômeno de El-Niño de todo século vinte, com a conversão para a costa leste do continente Sul Americano, sobretudo para o Sul do Brasil, de uma forte advecção de umidade (Dessay et. al , 2003). Geralmente o fenômeno ENOS - El Niño - Oscilação Sul - não

\footnotetext{
3 U.S. Department of Commerce National Oceanic and Atmospheric Administration http://www.elnino.noaa.gov/ acesso em o8/o7/2005 4 Plano Estadual de Recursos Hídricos: primeiro plano do Estado de São Paulo. DAEE, 1990.

5 HENKES, Silviana Lúcia. Histórico legal e institucional dos recursos hídricos no Brasil . Jus Navigandi, Teresina, a. 7, n. 66, jun. 2003. Disponível em: <http://www1.jus.com.br/doutrina/texto.asp?id=4146>. Acesso em: 11 jul. 2005.

6 PROMON ENGENHARIA S/A - 1977 - Retificação e outras melhorias do Rio Tietê: Determinação da linha média de enchente ordinária, São Paulo. PROMON / DAEE, São Paulo PROMON ENGENHARIA S/A -1977 - Retificação e outras melhorias do Rio Tietê: avaliação do efeito do Parque ecológico do Tietê sobre as vazões de cheia do Rio Tietê no município de São Paulo, PROMON / DAEE, São Paulo
} 
influencia significativamente o regime hidro-meteórico do sudeste. Mas, neste caso, contribui significativamente para uma maior irregularidade na distribuição das chuvas, alternando situações de secas (veranicos) com grandes aguaceiros. Já no estado de Santa Catarina seus efeitos foram devastadores. Chuvas excepcionais atingiram 75 mil dos $95 \mathrm{mil} \mathrm{Km}^{2}$ do estado, deixando 300.000 pessoas desabrigadas (Rebello, 1997). Foram também constatadas estiagens prolongadas na Região Nordeste e na Amazônia e fortes inundações no centro-sul do país, incluindo o estado de São Paulo e a capital paulistana. (Climanálise, 1987).

Já em 1983 as condições de circulação atmosféri- ca da fachada leste da América do Sul favoreceram a formação de sistemas semi-estacionários. Uma sucessão desses sistemas atingiu o sudeste do país, criando condições para a produção de chuvas intensas, inclusive no mês de junho.

Fazendo-se um levantamento de toda série histórica de dados pluviométricos da RMSP, desde 1890 até hoje, nota-se que o ano 1983 foi o que registrou maior volume de chuvas anuais, que coincide, também, com o período do mais forte fenômeno El Niño de todo o século vinte. Para a estação do IAG-USP, foi o único ano cuja pluviosidade superou os dois mil milímetros anuais - atingiu um volume total de $2.228 \mathrm{~mm}$ (Figura 5).

\section{Figura 5 - Histograma representativo da precipitação anual no período entre 1936 e 2000 (em mm) na Estação Meteorológica do IAG-USP}

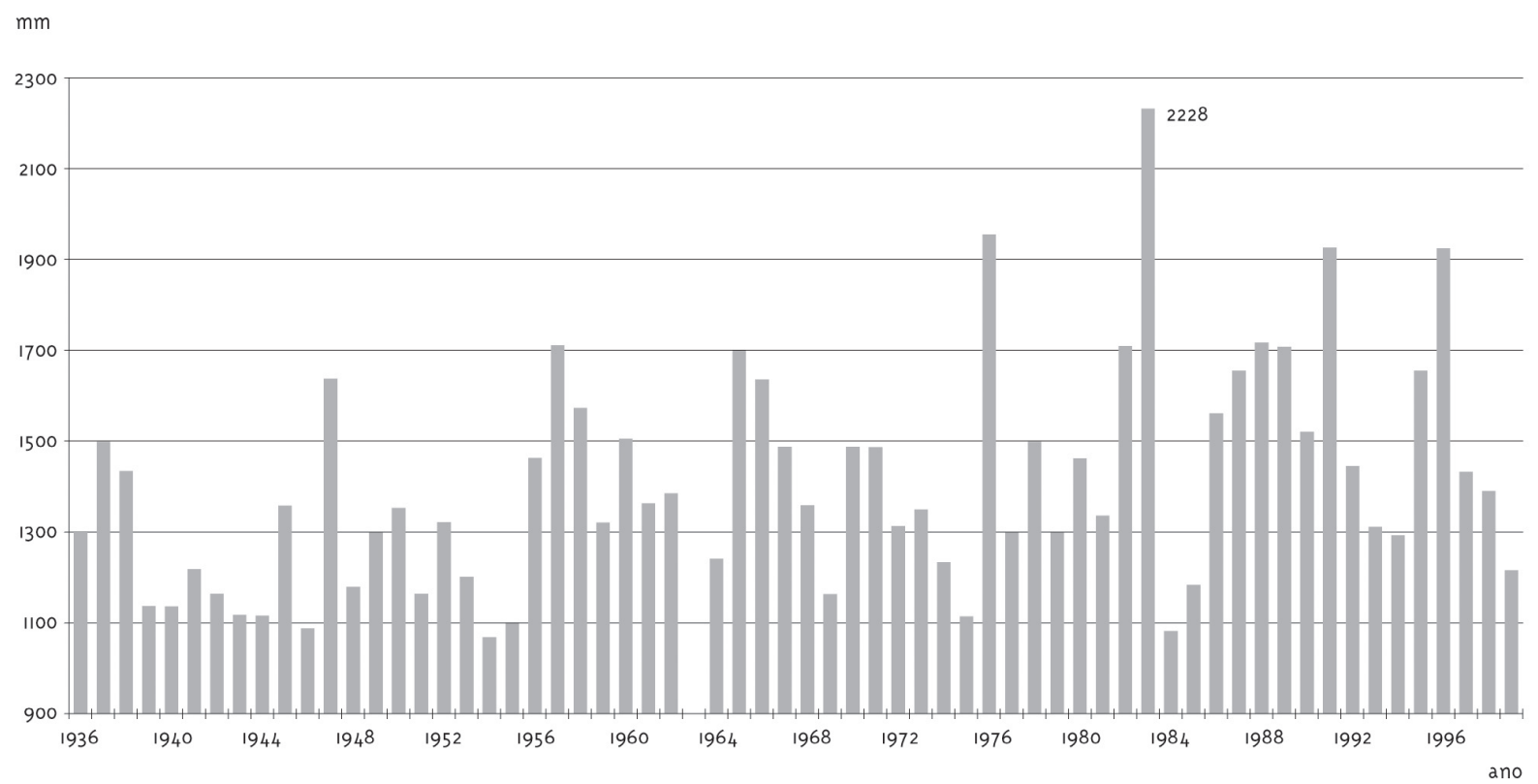

Fonte: DAEE - Banco de Dados Pluviométricos do Estado de São Paulo

As reportagens sobre as enchentes do período passaram a aparecer com destaque na imprensa, recebendo o status de calamidades públicas. As fotos do transbordamento dos rios e das tragédias urbanas começaram a estampar reportagens de capa dos principais periódicos. Ao mesmo tempo, apresentavam-se os recordes de vazão de cheia na Bacia do Alto Tietê sendo vencidos (Tabela 1). Nesta época, de acordo com Alves Filho (1996), a desorganização urbana, durante os principais episódios, chegou a impedir a circulação de pessoas e de mercadorias, com o extravasamento dos rios e com seccionamento da metrópole, tal como numa guerra civil, provocando sofrimento e morte para as populações menos assistidas. 
Tabela I - Vazões Máximas de Cheia na barragem de Edgard de Souza (Santana de Parnaíba) em episódios de enchentes na RMSP $\mathrm{m} 3 / \mathrm{s}$

\begin{tabular}{|l|c|}
\hline Data & Vazão $\left(\mathrm{m}^{3} / \mathrm{s}\right)$ \\
\hline 1900 & 462 \\
\hline 1923 & 358 \\
\hline $02 / 1929$ & 521 \\
\hline $02 / 1982$ & 755 \\
\hline $02 / 1983$ & 832 \\
\hline $06 / 1983$ & 697 \\
\hline
\end{tabular}

Fonte: Registros DAEE/Eletropaulo

Tal como numa guerra, estes episódios também legaram à metrópole seus campos de refugiados - os desabrigados das enchentes e dos desabamentos. No episódio de 05 e 06 de fevereiro de 1982, registraramse dez mortos, 1.613 pessoas desabrigadas, sendo que, destas, 642 perderam suas casas. Já, entre 04 e 05 de junho de 1983, ficaram desabrigados 1078 pessoas, 15 morreram vitimados pelas enchentes e por deslizamentos em áreas de risco ${ }^{7}$. Foram 63 ocorrências de desabamentos e soterramento de barracos, vitimando principalmente os moradores de favelas ${ }^{8}$.

Depois das grandes enchentes daquele período, que coincidiram com a gestão do governo Franco Montoro, foram aprovadas pelo CODEGRAN (Conselho Deliberativo da Grande São Paulo) e pelo CONSULTI (Conselho Consultivo da Grande São Paulo) as diretrizes metropolitanas para combate às enchentes, elaboradas pela EMPLASA - Empresa Metropolitana de Planejamento da Grande São Paulo SA 9. Foi realizado um inventário das áreas inundáveis na região metropolitana, com o objetivo de minimizar os impactos causados pelas enchentes, erosões e deslizamentos e orientar a ação do Poder Público.

Numa situação quase cíclica, após uma temporada de inundações, organizavam-se, e ainda se organizam, debates e seminários buscando soluções para o problema. Destes encontros, quase sempre surgem os novos planos de combate às enchentes a serem traçados nos gabinetes. Assim, com o decorrer dos anos, obras anti-enchentes também passaram a ser pontos prioritários nas campanhas político-eleitorais e, posteriormente, no repasse de recursos destinados às canalizações, às construções de galerias ou ao desassoreamento de córregos.

Outros episódios com grande repercussão ocorreram em 1987, novamente relacionados com a presença do fenômeno de El Niño Oscilação Sul (ENOS), repetindo as condições de circulação verificadas 1982/ 83. As águas, ligeiramente mais frias do Atlântico Norte e ligeiramente mais quentes do Atlântico Sul, favoreceram a formação de episódios de chuvas intensas, sobretudo na faixa litorânea do estado de São Paulo (Figura 6) (Climanálise - 1987).

\section{Figura 6 - Distribuição da pluviosidade no Brasil}

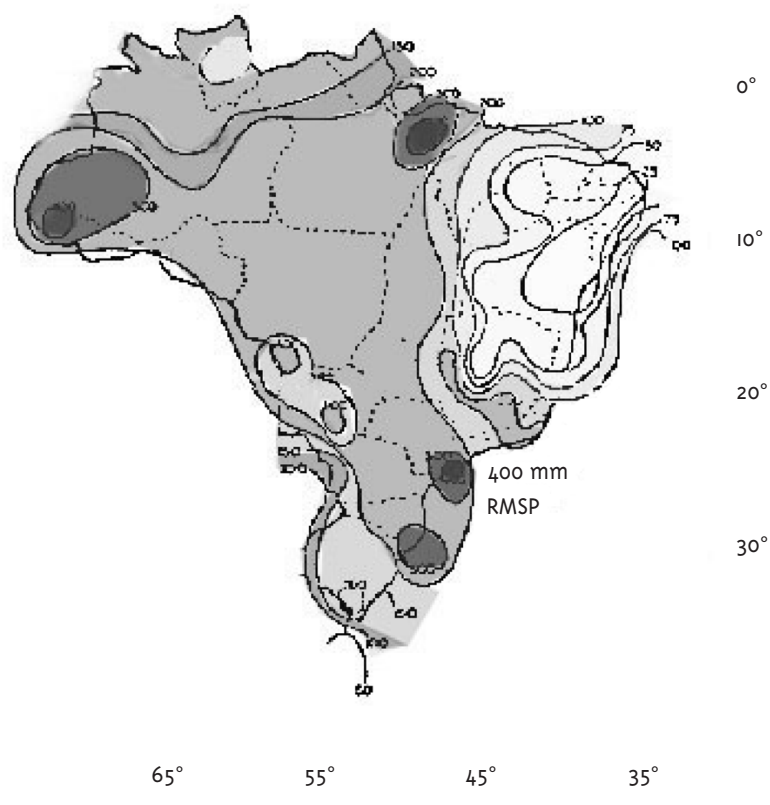

Adaptado de Climanálise oı/1987 P.4

7 Dados da Defesa Civil estadual

8 Secretaria das Administrações Regionais

9 Análise e Preposições Relativas às Enchentes na Grande São Paulo. São Paulo, jul. 1983, 44p.

Programa de Emergência de Combate às Enchentes na RMSP. São Paulo, 1983, 42p. 
O intenso aquecimento no interior do continente manteve condições propícias para a manutenção da convergência de umidade associada a um sistema semi-estacionário vinculado a uma área de baixa pressão (Depressão do Chaco), favorecida pelas circulações locais associadas à topografia e à brisa marítima. 0 fator orográfico foi decisivo para que ocorressem chuvas intensas (acima de $250 \mathrm{~mm}$ ) entre os dias 25 e 26 de janeiro. As inundações, provocadas pelos tributários da margem direita do Tietê à jusante, isolaram a zona norte da RMSP. Ao todo, foram computados, na RMSP, quarenta e cinco vítimas fatais e 6.500 desabrigados.

Em junho de 1987, repetiu-se um padrão semelhante ao observado em junho de 1983. Um sistema semiestacionário atuou por diversos dias sobre a RMSP, sendo detectadas anomalias na circulação atmosférica e nas temperaturas da superfície do mar pelo centro de análises climáticas dos EUA, (Climate Analysis Center-National Weather Services) (Climanálise, 1987 op. cit.). Esta situação repercutiu na tendência maior de parte dos sistemas frontais permanecerem estacionários no sul e sudeste, fazendo de junho de 1987 um mês com precipitações acima da média.

Naquele ano, na gestão do então governador Orestes Quércia, iniciou-se uma vultosa obra de aprofundamento da calha do Tietê, entre dois e meio e três metros de profundidade, ao longo de vinte e seis quilômetros de extensão à montante de Edgar de Souza, para aumentar a vazão desta barragem. A obra foi paralisada e retomada várias vezes. Pouco mais de dez por cento do previsto foi concluído no período.

Naquele mesmo ano, foi criado o Conselho Estadual de Recursos Hídricos, uma espécie de colegiado presidido pelo DAEE, que previa representantes de diversas secretarias de governo, universidades, institutos de pesquisa e representantes da sociedade civil, numa tentativa de solucionar os conflitos existentes pelos múltiplos aproveitamentos da água.

As enchentes de 20 a 22 de dezembro de 1988 provocaram grandes inundações, sobretudo na margem direita do Tietê, e elevaram o recorde de vazão de pico de cheia para 1.209 m³/s em Edgar de Souza. Já em julho de 1989, um sistema estacionário, que provocava chuvas fracas em São Paulo, recebeu reforço de um sistema frontal associado a uma zona baroclínica de $1000 \mathrm{hPa}$, propiciando uma grande convergência de umidade (3g/kg/dia) (Climanálise, o7/1989). As chuvas se intensificam a partir da madrugada do dia 30 , provocando inundações generalizadas, sobretudo à jusante da capital, em municípios como Osasco e Carapicuíba.

Naquela época houve a construção da "Barragem Móvel do Tietê" nas proximidades do "Cebolão", no interflúvio dos rios Pinheiros e Tietê, para eliminar o controle do canal à soleira de Edgar de Souza. Essa obra foi muito criticada por ambientalistas e vários segmentos da sociedade civil porque levaria a um despejo maior de esgotos não tratados na Represa Billings, transgredindo a constituição Estadual de 05/ 10/1989, que proíbe a poluição dos mananciais e a reversão das águas, salvo em episódios emergenciais. Também foram muito questionados os contratos de limpeza e desassoreamento do Tietê, dentro da cidade de São Paulo, apelidados de indústria da lama e realizados entre as gestões de Franco Montoro e Luiz Antonio Fleury Filho. Os mesmos foram julgados ilegais pelo Tribunal de Contas do Estado ${ }^{10}$.

Tiveram grande notoriedade, naquele período, as repetidas enchentes no Memorial da América Latina. A obra, projetada por Oscar Niemeyer, inaugurada em março de 1989, recebeu um enorme calçamento de concreto que impermeabilizou todo o solo, sem deixar uma única área verde para infiltração, a despeito de estar toda ela inserida na várzea da Barra Funda e ter um histórico de inundações bastante conhecido.

Talvez nada se assemelhe à percepção de caos urbano vivido por São Paulo no início da década de noventa. $O$ ano de 1991 foi particularmente marcado por grandes enchentes. A sensação de caos era reforçada pelo repetido assédio da imprensa e pelas manchetes dos principais jornais. Como nas cheias de 1929, os fatores hidro-meteóricos acabaram servindo de pano de fundo para o suprimento de interesses econômicos e políticos.

O conceito de calamidade publica, relacionado com as chuvas intensas, pode guardar certa dose de subjetividade, pois o que vai determinar seus efeitos será o tipo de resposta da drenagem para o escoamento das águas das chuvas.

10 Jornal da Tarde, 6/3/1995, p. 4 
É habitual, para a latitude de São Paulo, que ocorram muitos episódios de chuvas intensas e que vários destes tenham como desdobramento inundações. 0 que foi incomum, no caso de 1991, foi freqüência em que estas ocorreram e as repercussões que provocaram na metrópole. Mal a população se recuperava de uma inundação, outra ocorria na seqüência, não havendo, portanto, tempo hábil para a sociedade assimilá-las, ou seja, estes eventos ultrapassaram muitas vezes a capacidade de carga de meio antrópico.

Características específicas de circulação fizeram com que episódios de chuvas intensas se repe- tissem com uma freqüência quase quinzenal no primeiro quadrimestre do ano. Foram eles os episódios de 15 e 16 de janeiro, de 2 a 6 de fevereiro, de 18 de fevereiro, de 4 de março, de 19 de março, de 26 de março, de 16 de abril e de 24 e 25 de abril. 0 período mais crítico ocorreu em março de 1991. Este mês foi, até hoje, aquele com maior total de chuvas já documentado nos registros da cidade desde 1890. Considerando-se apenas os dados do IAG, a partir de 1936 pode-se verificar que não houve mês que tenha chegado perto dos valores encontrados em março de 1991(Figura 7).

\section{Figura 7 - Histograma representativo da precipitação acumulada mensal no mês de março entre 1936 e 2000 (em $\mathrm{mm}$ ) na Estação Meteorológica do IAG-USP}

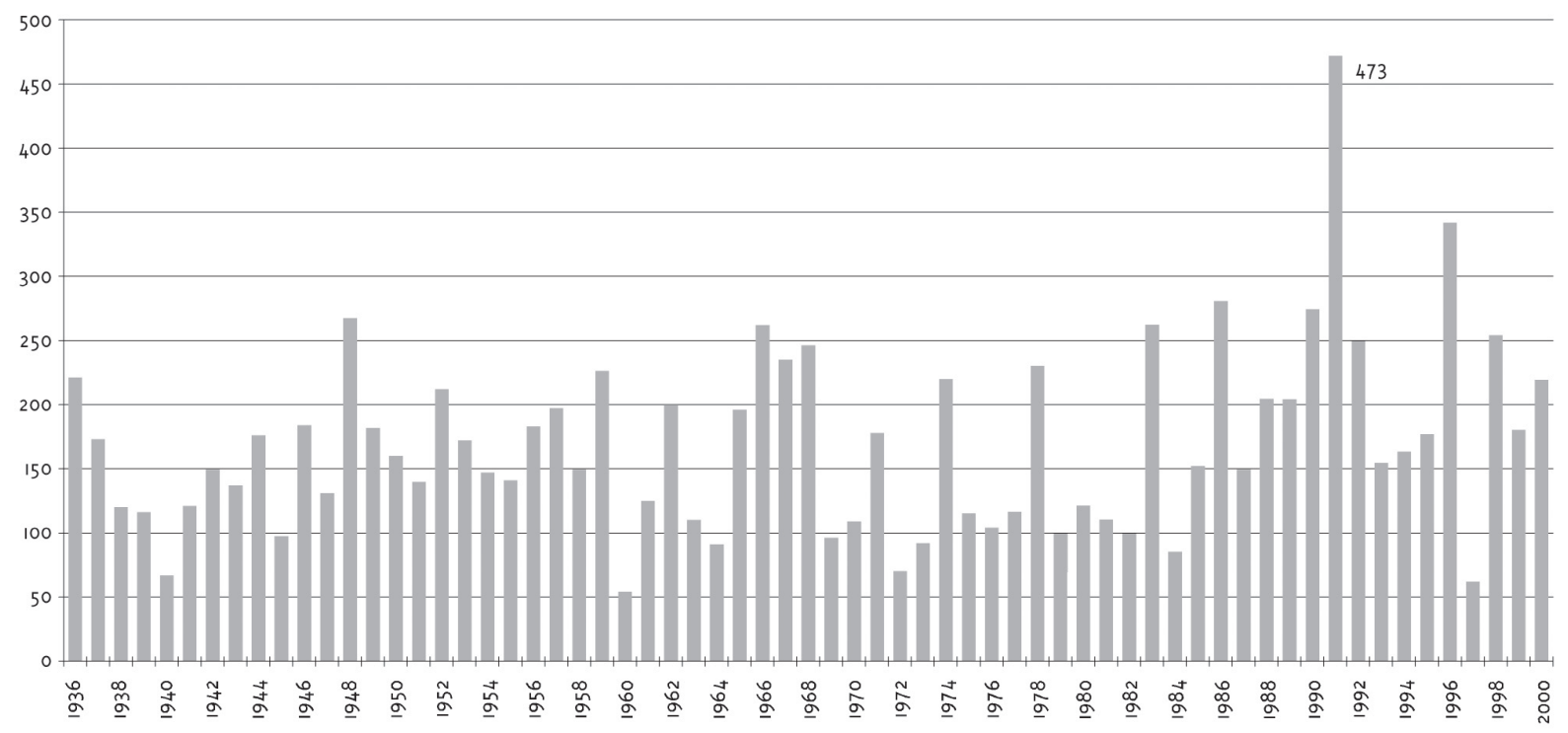

Fonte: DAEE - Banco de Dados Pluviométricos do Estado de São Paulo

Vários destes episódios ocorreram unicamente sobre a RMSP, sendo que nas adjacências e áreas não urbanas muitas vezes sequer chegou a chover. $O$ fato não deixa de ser um forte indício da influência antrópica na potencialização das chuvas. Em outras situações, as áreas de instabilidade acabaram convergindo para São Paulo. Já nos fenômenos de natureza mais abrangente em termos espaciais, como a penetração de um sistema frontal, a porção central da mancha urbana da Grande São Paulo foi a que apresentou, na maioria das vezes, a maior precipitação ao longo da passagem da Frente Polar Atlântica - FPA. Foram raros os casos nos quais o centro da metrópole não protagonizou os maiores impactos pluviais durante os episódios.

Além das chuvas terem ocorrido de forma intensa e algumas vezes também de forma prolongada, a percepção de caos foi possivelmente alimentada por perturbações no ritmo das atividades humanas. Situações de volta às aulas (segunda-feira) após uma temporada de férias, a véspera de um feriado prolongado (semana santa) ou uma greve geral de ônibus, que neste 
caso específico se arrastou por muitos dias de março, podem, em situações atmosféricas favoráveis, ter contribuído com o incremento das chuvas, de acordo as proposições de Alves Filho (2003). Pode não ser apenas coincidência que, em 23 eventos acima de $20 \mathrm{~mm} /$ dia, estudados no período, nenhum tenha ocorrido num final de semana e que chuvas convectivas, que são tipicamente induzidas por calor, tenham ocorrido nas situações supracitadas.

A circulação atmosférica naquele ano foi influenciada por um El Niño de longa duração (1990 a 1995), porém irregular (Fuentes, 1996). Muitas vezes o "El Niño" favorece a ocorrência de instabilidade atmosférica localizada, com a formação de nuvens convectivas tipo cumulus-nimbus, responsáveis por grande parte dos episódios de inundações.

As enchentes provocadas pelas chuvas intensas de março serviram de munição para os opositores do governo municipal. $\mathrm{O}$ fato de uma mulher, nordestina e de tendência política à esquerda, estar na época à frente do poder na mais importante metrópole do país incomodava seguimentos conservadores que eram representados na esfera federal pela eleição do Presidente Fernando Collor de Mello (Singer, 1996). Além disso, a Prefeita Luiza Erundina, chefe do executivo à época, havia sido eleita com apenas $28,5 \%$ dos votos contra 23,4 \% do segundo colocado, Paulo Maluf, pois na ocasião não havia segundo turno para eleições municipais. Outro grande problema é que o partido da prefeita na época (PT - Partido dos Trabalhadores) não contava com maioria na Câmara Municipal. Apesar de ser difícil imputar um culpado para o problema, uma vez que ele advém de um processo histórico de longa data, grande porção da opinião pública e dos órgãos de imprensa atribuiu à prefeitura a maior parte da responsabilidade sobre o problema, sem considerar que os principais rios que cortam a metrópole são operacionalizados pelo Governo do Estado.

A situação mais grave ocorreu em dezenove de março, quando municípios do $\mathrm{ABC}$ e a cidade de São Paulo ficaram literalmente imobilizados e a responsabilidade recaiu, mais uma vez, sobre a prefeitura de São Paulo por não haver investido em obras contra enchentes, segundo a mídia e os políticos de oposição. Num jogo de empurra, a Prefeitura defendeu a hipótese de que o DAEE (Departamento de Águas e Energia Elétrica) teria aberto as comportas da barra- gem de Ponte Nova no Alto Tietê à montante da capital, sob sua responsabilidade, enquanto que Eletropaulo, que gerenciava a barragem de Edgard de Souza, teria fechado sua vazão à jusante. Esta conjugação de elementos teria represando as águas do Tietê no trecho em que ele passa dentro do município. Os indícios deste possível erro são reforçados pelo grande tempo de recorrência entre final das chuvas, que terminaram por volta das treze horas, e o pico de vazão de cheia, que ocorreu às dezesseis e trinta, sendo que os transbordamentos só cessaram sete horas após o final das chuvas.

Outro problema que supostamente contribuiu para o agravamento das enchentes, naquele período, foi o fato de algumas empreiteiras terem abandonado as máquinas e também entulhos no leito de alguns córregos que estavam sendo canalizados, pois a prefeita havia suspendido temporariamente algumas obras contratadas na administração anterior (Jânio Quadros), quando assumiu o cargo. A justificativa na época foi a existência de uma dívida de US\$ 3.988 bilhões contra uma receita de apenas US\$ 3.023 bilhões. De acordo com Marques e Bichir (2001), os prefeitos da capital paulista de linha política mais à esquerda tenderam a construir muitas obras de pequeno e médio valor, pouco aditadas e contratadas com empresas de capital mais modesto em relação aos políticos de direita.

As grandes enchentes de 1991, o enorme espaço que o assunto tomou na mídia e, também, a exploração política dos fatos levaram a um aumento considerável do investimento em recursos hídricos daquela época em diante, tanto na esfera estadual quanto federal.

Nesse período inicia-se, também, a campanha para despoluição do Tietê, um marco do ambientalismo brasileiro. A partir de uma iniciativa popular, liderada pela ONG - SOS Mata Atlântica e veiculada por uma rádio da capital, a campanha chegou a recolher 1,2 milhões de assinaturas em prol da despoluição rio. 0 governo do estado encampou o projeto e acabou obtendo financiamento do BID (Banco Interamericano de Desenvolvimento). 0 projeto conseguiu importantes avanços como a queda drástica da emissão de efluentes industriais. Porém, como em muitas outras obras públicas, pairam denuncias de malversação de dinheiro público. Nesse caso, estes indícios acabaram provocando o cancelamento de trinta e um contratos, em 1995. Mas isto seria tema para outra pesquisa. 
Na gestão seguinte, a do prefeito Paulo Maluf, inaugura-se a era da construção dos reservatórios de contenção - os piscinões. O primeiro destes foi construído no bairro do Pacaembú, na capital. Logo, estes reservatórios transformaram-se numa estratégia utilizada por diversos municípios da RMSP para dar cabo às enchentes.

Os piscinões, ao contrário das obras de canalização de córregos, têm a grande vantagem de retardar o escoamento das águas nos episódios de chuvas intensas. Porém, a despeito de toda a técnica apurada, obedecem de certa forma ao mesmo modelo de uso e ocupação do solo: conquista-se a várzea, impermeabiliza-se uma extensa área do solo e mais tarde, quando começam a ocorrer inundações, recorre-se à construção de reservatórios para conter o excesso de vazão da água. Essas várzeas, tornadas enxutas depois das obras, vão se transformar em poderosas e amplas vias de circulação e avenidas de fundo de vale e abrir caminho para que, em seus terrenos contíguos, haja espaço para grande valorização e especulação imobiliária.

Um outro grave problema destes reservatórios, constatado alguns anos mais tarde, é que construí-los é uma tarefa mais fácil do que mantê-los limpos e desassoreados. Assim, com o passar dos anos, eles se transformam em problemas ambientais e de saúde pública, pois não deixam de ser grandes áreas de esgoto a céu aberto, provocando mau cheiro, acumulando lixo e potencializando a proliferação de doenças. Além disso, no período de chuvas, uma imensa quantidade de solo exposto e a maior parte da poluição difusa podem ser carreadas para dentro dos piscinões, que, assoreados, deixam de cumprir o seu papel - ao invés de reter a água, passam a extravasar e provocar enchentes. Não é tão fácil resolver os problemas ambientais da cidade.

Uma nova temporada de grandes episódios de inundação ocorreu em fevereiro de 1995. A estação meteorológica do IAG-USP acusou a pluviosidade de 439,6 mm/mês, a maior da história, se levarmos em conta que o mês de fevereiro é mais curto que os demais. Nesse mês, uma situação de bloqueio, provocada pelo estacionamento de um anticiclone sobre Minas Gerais e Bahia, propiciou a formação de sistemas es- tacionários sobre o sul do país e São Paulo.

Alguns dos episódios de chuvas intensas foram provocados pelo deslocamento de VCA(S) - Vórtices Ciclônicos de Altos Níveis para a região. Naquele ano, o símbolo da situação de miséria urbana foi representado pelos quinze dias de alagamentos de alguns bairros da zona leste, como a Vila Itaim e a Favela Pantanal. As constantes inundações e protestos de moradores deram ao fato grande cobertura da imprensa.

No ano seguinte, foi lançado o Plano Diretor de Macrodrenagem da Bacia do Alto Tietê, que incluiu a retomada das obras de rebaixamento e alargamento da calha do rio Tietê, iniciadas no governo Quércia e ainda canalizações, instalação de emissários de esgoto, construções de barragens e de mais reservatórios de contenção (piscinões).

As obras passaram a ser custeadas pelo Japan Bank for Internacional Cooperation (JBIC) e pelo tesouro paulista. Os custos das obras, que tiveram uma elevação de $148 \%$, muito acima dos $25 \%$ previstos pela lei nº 8666 (Lei das Licitações), são alvos de contestação pelo Tribunal de Contas do Estado ${ }^{11}$.

Poderíamos ainda descrever tantos outros episódios que se sucederam tais como os ocorridos em janeiro e fevereiro de 1996, janeiro de 200o, outubro de 2001, porém a narrativa de tais eventos se tornaria repetitiva, pois não acrescentaria fatos novos na discussão sobre a percepção ambiental de caos urbano. Porém, um fato que poderá servir como proposição para futuras investigações refere-se ao nítido arrefecimento dos episódios de chuvas intensas a partir de 1997. Algumas explicações de macro-escala podem ser dadas para fato, destacando-se a menor intensidade dos fenômenos El Nino, neste dado período, ou ainda a hipótese que estaríamos entrando num ciclo frio da ODP - Oscilação Decadal do Pacífico, cuja fase quente ocorreu entre 1976 e 1998. Aceitando-se a hipótese que a ODP seja importante controlador do clima global, a tendência para o país seria a redução dos totais pluviométricos e uma melhor distribuição de chuvas dentro do ciclo anual. (Molion, 2005). Porém, faz-se necessária uma investigação mais detalhada para discutir as tendências para os próximos anos.

11 Tribunal de Contas do Estado de São Paulo - Processo TC-15.528/o26/o1: Exame do Edital da Concorrência Internacional nº oo4/ DAEE/2001/SUP, 
Embora a Figura 3, mostrada no inicio do artigo, indique uma tendência geral ao aumento da pluviosidade nos últimos sessenta anos, houve uma ligeira queda nas médias de pluviosidade na última década. De acordo com a Figura 8, que expressa os dados da estação Meteorológica do Aeroporto de Congonhas, pode-se perceber uma queda nos dias de chuvas com totais pluviométricos acima de 40 milímetros, o que é um indicativo destas mudanças. Já os dias de chuva com totais acima de oitenta milímetros também caíram. Esses dados são importantes, pois eventos diários acima de 80 milímetros são indicativos de episódios de inundações.

Outra constatação importante, possível de se observar a partir da Figura 9, é que o maior número de episódios acima de $40 \mathrm{~mm}$ ocorreu em anos de El Nino (1983-1991). Em relação aos dias de chuva acima de 80 mm eles ocorreram em sete anos do decênio 19821991 e em apenas três anos do decênio seguinte (19922001).

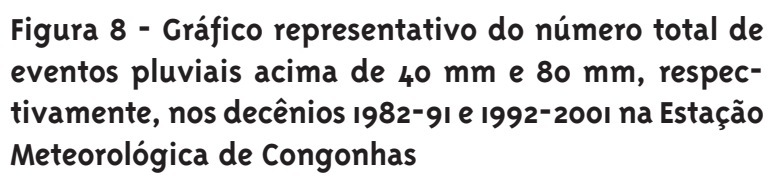

$N^{\circ}$ de eventos

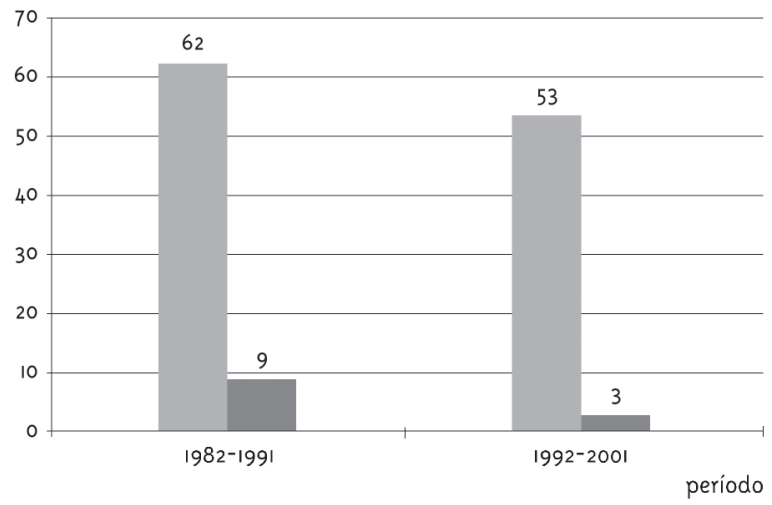

Legenda

mais $40 \mathrm{~mm}$ mais $80 \mathrm{~mm}$

Fonte: DAEE - Banco de Dados Pluviométricos do Estado de São Paulo.

Figura 9 - Gráfico representativo do número total de eventos pluviais acima de $40 \mathrm{~mm}$ e $80 \mathrm{~mm}$, respectivamente, entre 198ı e 200। na Estação Meteorológica de Congonhas

$\mathrm{N}^{\circ}$ de eventos

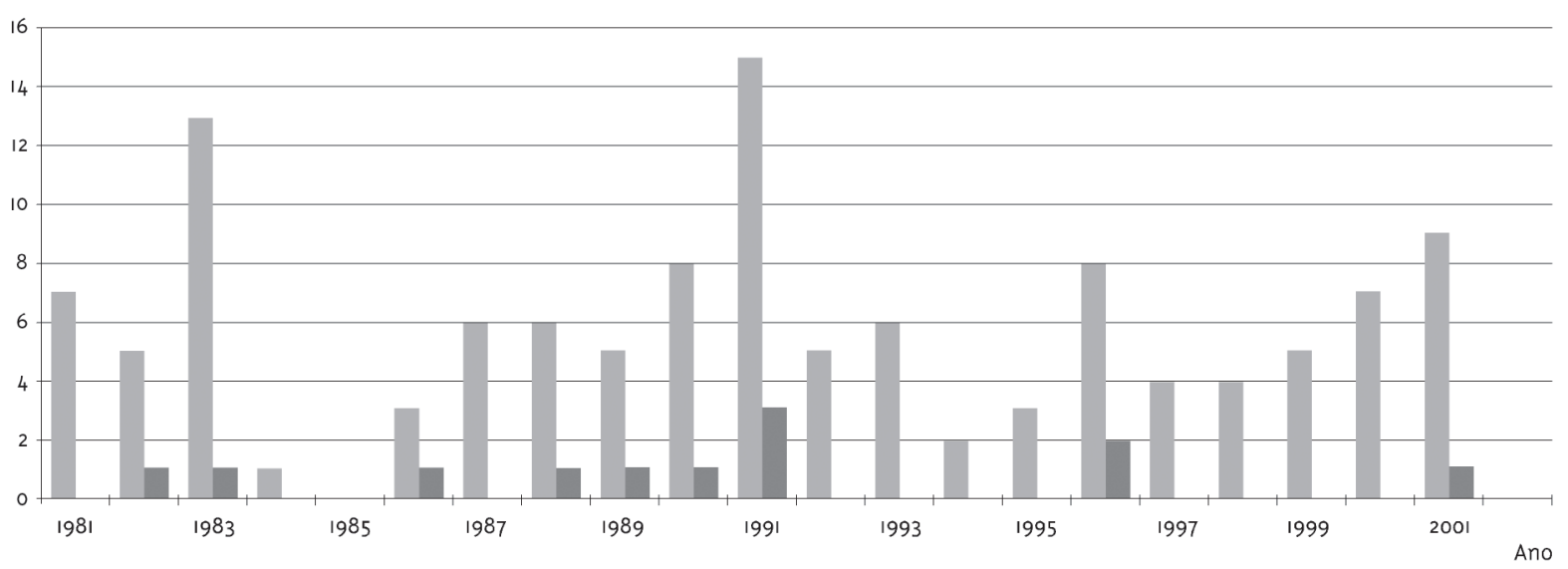

Legenda

$\square \mathrm{N}^{\circ}$ de eventos (> de $\left.40 \mathrm{~mm}\right) \square \mathrm{N}^{\circ}$ de eventos $(>80 \mathrm{~mm})$

Fonte: DAEE - Banco de Dados Pluviométricos do Estado de São Paulo. 
Portanto, a avaliação feita por algumas instâncias governamentais de que houve redução no número de enchentes na RMSP pode ser procedente. O que será muito difícil definir é até que ponto isto ocorreu por conta das benfeitorias realizadas ou por componentes climatológicos. Tal ponderação mereceria um estudo detalhado.

O problema das enchentes reapareceu com intensidade em 2005. Quando as obras de aprofundamento da calha pareciam ter solucionado o problema das inundações na Bacia do Alto Tietê e outdoors espalhados pelas marginais anunciavam ofim das enchentes, um episódio de chuvas intensas, que suplantou $140 \mathrm{~mm}$ em menos de $24 \mathrm{~h}$ em alguns pontos da capital, deu cabo, por enquanto, desta expectativa.

A sensação de caos, já descrita muitas vezes neste trabalho, se repetiu. Novas promessas de obras antienchentes e novos piscinões voltaram a fazer parte do repetitivo discurso dos governantes. De acordo com Marques e Bichir (2001 op. cit.), a organização territorial de São Paulo foi historicamente direcionada para solucionar problemas viários ou de drenagem de curto prazo, apesar da existência de propostas mais abrangentes. Custódio (2001) trabalhou com a análise do discurso que acompanha os episódios de enchentes na Grande São Paulo, ressaltando a ineficácia de muitas das soluções tomadas, que para a autora seriam reflexos de um processo decisório pouco participativo, ainda hoje.

Embora exista um plano de macro-drenagem, que prevê a participação de instancias não governamentais na discussão das prioridades, percebe-se nitidamente que as prioridades revelam-se difusas, se levarmos em conta os interesses das comunidades atingidas pelas inundações e seus respectivos poderes de barganha.

\section{Considerações Finais}

Pode-se dizer que a história da formação da metrópole paulistana entrelaça-se com a história da apropriação dos recursos hídricos pelos setores com forte financiamento, como o da geração de energia e o da especulação imobiliária, em detrimento dos seus demais usos.

Domar o rio, retificar seu leito e apropriar-se de suas várzeas, ou simplesmente engoli-lo, sepultando-o em galerias sob avenidas de fundo de vale, foi, invariavel- mente, a estratégia de dominação imposta pelo poder econômico há mais de um século. De acordo com os paradigmas de Lacoste (1993), uma das expressões do exercício do poder é o domínio do espaço geográfico.

Esta apropriação do território se dá de várias maneiras, uma destas é a de basear o seu ordenamento na segregação e controle dos recursos existentes, como, por exemplo, o gerenciamento das águas e de sua captação. No caso da metrópole paulistana, há um açambarcamento dos recursos hídricos em uma área que transcende em muito os limites da Bacia Hidrográfica do Alto Tietê.

Atualmente, este controle ocorre inclusive em nível global. Segundo Petrella (2002), a dominação do capital financeiro sobre os recursos hídricos faz parte da estratégia de mercantilização de tudo: dos genes, do solo, da água, enfim, da natureza. Segundo este autor, um dos instrumentais utilizados para tal controle estaria ligado às modalidades de financiamento praticadas pelas agências de fomento multilaterais, tais como o BID (Banco Interamericano de Desenvolvimento), o JICA (Japan International Cooperation Agency) e o Banco Mundial, que consideram os recursos hídricos como sendo um bem privado. Para estes, o acesso à água potável, à rede de esgotos ou a terrenos enxutos e livres de inundações com águas contaminadas, não seria um direito, mas sim uma regalia aos que podem pagar por isso.

No caso do Brasil, a maior parte dessa modalidade internacional de empréstimos começou a chegar ao país em 1992. As grandes inundações de 1991, aqui relatadas, acabaram servindo de justificativa para aporte de grandes somas de recursos, da ordem de mais de bilhão de dólares, para serem investidos na Bacia do Alto Tietê, nos anos subseqüentes, tanto para despoluição, quanto para combate às enchentes. Embora haja avanços perceptíveis, estes programas chegam até a atualidade com resultados concretos discutíveis, se levarmos em conta a relação custo/benefício. Além disso, os proveitos de todo este investimento não são democraticamente distribuídos e também não livraram, até hoje, a população das periferias pobres do drama das enchentes, pelo contrário, a cada ano são cada vez mais freqüentes os relatos de dramas locais potencializados pelas enchentes.

Segundo o último censo do IBGE - Instituto Brasileiro de Geografia e Estatística, houve um crescimen- 
to de $30,2 \%$ da população nas favelas em relação ao censo anterior, no entanto, a população total, no mesmo período, cresceu apenas $8 \%{ }^{12}$. Segundo os dados de FIPE / SEHAB, 50,7\% das favelas e 71,9\% dos domicílios favelados estão localizados à margem de córregos, sendo que grande parte destes são sujeitos a inundações periódicas ${ }^{13}$.

Pode-se afirmar, portanto, que estes problemas agravaram-se, na medida em que aumentou o número de pessoas potencialmente vítimas do problema, fato largamente comprovado pelas inundações de janeiro de 2006, que atingiram em cheio a população da periferia da metrópole e provocaram muitas perdas materiais e humanas.

Frente aos recursos destinados às obras hidráulicas e à despoluição dos rios, o investimento na avaliação climática é extremamente modesto. Além disso, está mais adequado ao dimensionamento e monitoramento hidráulico do que propriamente ao estudo do clima. Portanto, trabalhar com esta exigüidade de recursos disponíveis constitui-se num desafio para os climatologistas e demais pesquisadores que se adjudicam desta tarefa.

No entanto, este objetivo deve ser perseguido com afinco. 0 primeiro passo para se reverter este quadro de apartamento social e garantir o acesso eqüitativo das benfeitorias implantadas com recursos, que serão pagos pelo contribuinte, mais cedo ou mais tarde, é o de criar a consciência da real dimensão dos problemas e demonstrar que riscos ambientais, como aqueles desencadeados por chuvas intensas, afetam de forma diferenciada diversos segmentos da população.

No pano de fundo desta discussão está o confronto entre duas visões: de um lado prevalece o discurso tecnicista que procura adaptar a cidade aos interesses estratégicos que tentam perpetuar as estruturas vigentes de reprodução do capital e do outro surgem segmentos na sociedade que pretendem superação da exclusão social na qual se encontram grandes parcelas da população das metrópoles brasileiras, através de ações políticas das mais variadas origens e dimensões.
Na medida em que existem grandes diferenças na maneira pela qual cada parcela da população afeta ou é afetada pelo clima, os estudos no campo da climatologia geográfica não se constituem num fim em si mesmo, pois não estão isentos de engajamento em uma das duas posições supracitadas. Podem servir de reforço para a estrutura dominante ou, pelo contrário, podem ajudar subsidiar, através de um melhor conhecimento do meio ambiente urbano, uma ação transformadora dentro da sociedade.

\section{Referências}

ALVES FILHO, A. P. Episódios pluviais intensos na região metropolitana de São Paulo: uma avaliação no decênio 1982-1991. 1996. Dissertação - Departamento de Geografia da FFLCH da Universidade de São Paulo. São Paulo, 1996.

ALVES FILHO, A. P. O ritmo climático e as enchentes de 1991 na região metropolitana de São Paulo: uma analise através do radar meteorológico. 2003. Tese FFLCH da Universidade de São Paulo. São Paulo, 2003.

AMBRIZZI, T. Crise e chuvas: uma visão meteorológica. Jornal da USP, São Paulo, n. 556, jul. 2001. Caderno especial, p. 4-5.

CLIMANÁLISE - Boletim de monitoramento e análise climática, São José dos Campos, SP, INPE/CPTEC (volumes 1 ao 6), 1987.

CUSTÓDIO, V. I. A persistência das inundações na grande São Paulo. 2001. Tese - Departamento de Geografia da FFLCH da Universidade de São Paulo. São Paulo, 2001.

DESSAY, N. et al. Comparative study of 1982-1983 and 1997-1998 El Niño events over different types of vegetation in South America. International Journal of Remote Sensing, London, v. 25, n. 20, p. 4063-4077, Oct. 2004.

ELETROPAULO. Rios, reservatórios, enchentes. São Paulo: Departamento de Patrimônio Histórico da Eletropaulo, 1995. (Série História \& Energia).

12 IBGE - Instituto Brasileiro de Geografia e Estatística. Censo demográfico 200o. Rio de Janeiro: IBGE, 2002.

13 FIPE/SEHAB (1994) Estudo das favelas e cortiços na cidade de São Paulo, visando conhecer em profundidade as condições a atuais destes tipos de agrupamentos urbanos para servir de orientação aos programas para população de baixa renda e reassentamento urbano da SEHAB - Relatório Final: Favela, vol. 1, São Paulo 
FUENTES, M. V. Bloqueios. Climanálise, São José dos Campos, v. 11, out., p. 70-89, 1996. Edição /especial Comemorativa de 10 anos.

LACOSTE, Y. A geografia, isso serve, em primeiro lugar, para fazer a guerra. 3. ed. Campinas: Papirus, 1993.

MARQUES, E. C.; BICHIR, R. M. Padrões de investimentos estatais em infra-estrutura viária. São Paulo em Perspectiva, São Paulo, v.15, n.1, p.60-72, jan./mar. 2001. MASSARI, M.; REYDON, B. P. O embate entre o comitê do alto Tietê e o do PCJ pela Água do Jaguari: cobrança pelo uso seria uma solução? Campinas: Instituto de Economia - Unicamp, 2005. Disponível em: <http:// www.eco.unicamp.br/nea/gestao_ambiental/ textosparadiscussao/Comite_Alto_Tiete.doc>. Acesso em 1 jul. 2005 .

MOLION, L. C. B. Aquecimento global, El Niños, Manchas solares, Vulcões e oscilação Decadal do Pacífico. Climanálise - Notas técnicas, n. 1, ano 3, p. 1-5, agosto de 2005 .

MONTEIRO, C. A. F. Environmental problems in São Paulo metropolitan area: the role of urban climate with special focus on flooding In: IGU Commission on Environmental Problems: Problems of the Environment in Urbanized Regions. Proceedings of Symposium of the UGI Commission on Environmental Problems, 1980, Tokyo. Moscow: IGU, 1984. p. 17-38.

PETRELLA, R. I. O manifesto da água, argumentos para um contrato mundial. São Paulo: Vozes, 2002.

PROMON ENGENHARIA S/A. Retificação e outras melhorias do Rio Tietê: determinação da linha média de enchente ordinária. São Paulo: PROMON: DAEE, 1977a.
PROMON ENGENHARIA S/A. Retificação e outras melhorias do Rio Tietê: avaliação do efeito do Parque Ecológico do Tietê sobre as vazões de cheia do Rio Tietê no município de São Paulo. São Paulo: PROMON: DAEE, 1977b.

REBELLO, E. Anomalias climáticas e seus impactos no Brasil durante o evento ‘El Niño' de 1982-83 e previsão para o evento 'El Niño' de 1997-98. In: Cadier, E. G. et al. Consecuencias climaticas e hidrologicas del evento el nino a escala regionaly local: incidencia en America del Sur. Montevideo: Edición Internet. Unesco, 1998. http://www.unesco.org.uy/phi/libros/enso/henin.html. Acesso em: 1 julho 2005.

SÃO PAULO (Estado). Conselho Estadual de Recursos Hídricos. Plano Estadual de Recursos Hídricos: primeiro plano do Estado de São Paulo. São Paulo: DAEE, 1990.

SEABRA, O. C. L. Os meandros dos rios nos meandros do poder: Tietê e Pinheiros - valorização dos rios e das várzeas na cidade de São Paulo-SP. 1987. Tese - Departamento de Geografia da FFLCH da Universidade de São Paulo, 1987.

SILVA, R. A. E. A evolução econômica. In: A cidade de São Paulo: estudos de geografia urbana. São Paulo: Nacional, 1958.

SINGER, P. Um governo de esquerda para todos: Luiza Erundina na prefeitura de São Paulo (1989-1992). São Paulo: Brasiliense, 1996.

VICTORINO, V. I. P. Monopólio, conflito e participação na gestão dos recursos hídricos. Ambiente \& Sociedade, Campinas, v. 6, n. 2, p. 47-62, 2003.

Recebido em: 18/01/2006

Aprovado em: 12/06/2006 